\title{
Lives on Hold: ESL in a Restructured Society
}

David Cooke

A survey of ESL in Auckland, New Zealand, in the light of the pervasive restructuring of society and education in the last 15 years finds that the lives of adult immigrants are difficult and precarious. Many realize their previous training and experience are unsuitable for their chosen occupations, and so they have to make drastic career changes. Their main contact with fluent English is largely limited to ESL classes rather than the English environment around them. New Zealand government immigration policies seem opportunistic and discriminatory. Institutions face difficulties in funding some ESL programs and so encounter problems in planning and continuity.

À Auckland, en Nouvelle Zélande, une étude de ALS dans le contexte d'une restructuration profonde de la société et l'éducation depuis les 15 dernières années a révélé que la vie des immigrants adultes y est difficile et précaire. Plusieurs parmi eux se rendent compte que leur formation et leurs expériences antérieures sont mal adaptées à leur profession et qu'ils doivent donc entreprendre des changements de carrière radicaux. Leur contact le plus important avec l'anglais courant s'effectue le plus souvent en salle de classe ALS plutôt que dans l'environnement anglais où ils vivent. Les politiques sur l'immigration du gouvernement de la Nouvelle Zélande semblent opportunistes et discriminatoires. Les problèmes de financement relatifs à certains programmes ALS que connaissent les institutions rendent difficiles la planification et la continuité.

Over the last 15 years, New Zealand society has gone through radical restructuring following the Lange Labour government's initiatives in the mid-1980s to move the country from a welfare state to an entrepreneurial, market-based economy (Easton, 1997; Else, 1996; Kelsey, 1995, 1999; McQuaig, 1995; Richardson, 1996). This restructuring has had profound effects on many aspects of society, including education: converting the Department of Education into a Ministry of Education; turning all schools effectively into charter schools complete with boards of trustees; and deregulating educational institutions (Dale \& Robertson, 1997; Roberts, 1997, 1998). Among other outcomes, there has been an explosion of offerings and programs as institutions have diversified into fields not previously sanctioned or envisaged: for example, both polytechnics and universities have moved into teacher education (formerly the domain of teacher training colleges), and 
many institutions have established programs in English for speakers of other languages (ESOL) (Kennedy \& Dewar, 1997).

One of the reasons for the expansion of ESOL programs is increased demand brought about by government policies in the early 1990s to open the doors to a widened pool of immigrants, but targeting Southeast Asia in particular. The outcome has been an influx of migrants from various parts of the world, but especially from the so-called Asian Tigers such as Taiwan, Hong Kong, and South Korea. New Zealand, with a population of about 3 million, has aimed at around 40,000 immigrants per year, usually falling short of this number (Bedford \& Bedford, 2000). By contrast, Canada, with a population between 25 and 30 million, aims for approximately $220,000 \mathrm{im}$ migrants per year.

The major reception area for immigration into New Zealand is the greater Auckland area. A city of over 1 million, Auckland has a diverse ethnic and racial population, including European, Maori, Pacific Islands, and Southeast Asian residents. It has a large concentration of educational institutions, many of which provide language instruction, including ESL.

New Zealand's social restructuring is part of the process of globalization and structural adjustment actively promoted worldwide (Mander \& Goldsmith, 1996) and currently driving much of the political, social, and economic change of countries like Canada (Barlow \& Campbell, 1995; Clarke, 1997; Clarke \& Barlow, 1997; Dobbin, 1998). There may well be implications for other countries from the developments in New Zealand, especially the country's move to "resite" itself to attract business and immigration from Southeast Asia (compare Dale \& Robertson, 1997, whose account might be compared to Simmons, 1997, who describes Canada's immigration policy as "pragmatic" and "entrepreneurial").

The process of restructuring was the context of a focused survey of the delivery of ESL in Auckland in July and August 1998, which included 28 audiotaped interviews with 42 participants (students, teachers, and administrators) from two polytechnics, two public schools, and one private school. The interviewees consisted of 30 learners (14 at secondary school, 16 at polytechnic), three teacher-administrators, one director of a language school, seven teachers of ESL, and an immigration consultant. Interviews ranged from 15 minutes to over an hour long. All were transcribed and scrutinized, first, for responses to the separate questions posed (see Appendix). Then the transcribed texts were analyzed for the emerging themes related to the complex and contested situation of the migrant in New Zealand (the focus of the current discussion). It became increasingly clear in the interviews that the immigrants and the teachers had significant stories to tell about the process and effects of immigration and of New Zealand's immigration policy. The inquiry, therefore, had a two-pronged approach: first, to explore the extent to which the education providers were meeting the needs of ESL learners under 
the restructuring of society taking place; and second, to explore the situation of the migrant faced with limited opportunity in a society that lacked a resettlement policy.

Basically like Canada, New Zealand has established four categories of immigration: General (by far the largest category, which uses a point system somewhat similar to Canada's); Business (for migrants with enough financing to start businesses); Family reunification; and Refugees. All the migrants interviewed in the survey came from the General or Business categories. The survey did not inquire into the situation of refugees, a complex and controversial area of migration in the country.

The student interviews distinguished permanent residents (compare Canada's landed immigrants) from international students (compare Canada's visa students), asked their length of time in New Zealand, their year level at school, their aims in taking ESL and their current and future uses of English, and the likelihood of their staying in New Zealand or moving to other English- or non-English-speaking countries. Interviews asked a key question about whether current courses fitted the learners' aims, needs, and goals previously expressed, at the same time asking students their preferred and least preferred ways of learning English, as well as their estimate of progress in English (who or what helped them to learn English or, by the same token, made learning difficult). In the same vein the interviews asked about the extent to which learners made use of print, media, or personal contact in their learning and inquired about their motivation to learn the language. Students were also invited to give their recommendations for ESOL courses.

The interviews with teachers and administrators covered some of the same issues. They asked respondents to comment on their perceptions of the students' aims, needs, and goals in taking English and of the students' shortand long-term expectations. They asked about the extent to which the delivery of ESL programs accommodated the learners' goals; they also inquired into students' presumed motivation and abilities in English and the teachers' perceptions of students' preferred ways of learning. Related questions included the teachers' goals, the conditions of learning set up in their courses, their preferred language teaching procedures, and the extent to which they used published materials as contrasted with teacher-made or authentic materials. The interviews asked for the teachers' views of factors that encouraged or hindered learners' progress and invited teachers to comment on the extent to which ESOL had changed over the previous 15 years of restructuring in society. In addition, administrators were asked questions on the funding process or formulas for ESOL in their institution and a related matter: the definition of an ESOL student.

From the various different dimensions of the study, the following discussion focuses on the impact of social restructuring on ESL and on the lives of 
migrants, concentrating more on the adult immigrants at the postsecondary level than on high school students. It was apparent in formulating the study that the social changes that constructed a rigorous market economy in New Zealand in the 1980s and 1990s would have effects on education and immigration. In the course of conducting the study, it became clear that these effects were pervasive and in some cases drastic.

\section{The Social Context}

It is clear that in the latter decade and half of the 20th century New Zealand society has been remodeled, with emphasis on self-reliance and entrepreneurial activity. In the 1990s the New Zealand government set in motion large-scale immigration that led to many different educational institutions providing English language instruction. However, successive governments and varied political maneuvering have resulted in rapid shifts in official policies as outlined above.

In the process of immigration, the "principal immigrant" of a family is required to reach a given score on the International English Language Testing System (IELTS, a measure based in Cambridge, UK). In that immigrant's family second-language speakers of English have been required to post a $\$ 20,000$ bond (beyond any other fees submitted), tied to reaching a designated score on the IELTS within stipulated periods after arrival. Failure to gain the test score results in forfeiture of the bond.

Under this ... policy, all applicants aged 16 and over applying for entry under both the General Skills and Business Investor Categories are required to either provide evidence of having an English language background or pass level 5 of the IELTS test (level 4 for Business Investor migrants). Non-principal applicants who cannot attain this level of English can instead pay a $\$ 20,000$ bond, refundable in full if the required level can be achieved in 3 months and $70 \%$ refundable if the required level can be achieved in 12 months. (Forsyte Research, 1998, p. 1)

According to Forsyte Research (1998), the government's apparent reason for introducing the bond was to motivate migrants to learn English rapidly: "the language bond was intended to act as a strong incentive for applicants to learn English offshore or within a short time-frame after their arrival in New Zealand" (p. 2). Teachers interviewed were highly suspicious of the official reason, talking of it as evidence of the government's "mean-spirited" and exploitive approach to immigrants. If it was an additional way of raising revenue, the situation becomes more problematic. Until October 1997 the country had collected $\$ 4.72 \mathrm{~m}$ from a total of 236 bonds. Of that figure, 45 bonds were partly or totally refunded (Forsyte Research). In other words, the financial returns were slight, but achieved at the cost of alienating and disadvantaging many migrants and, just as important, prospective applicants. Moreover, teachers object that there is no evidence that any of the 
monies acquired through the bond flowed into language instruction to help migrants. It seems that negative responses to the bond resulted in the government withdrawing the requirement in late 1998.

Until 1998 full-time students had been eligible for a study allowance of about $\$ 100$ a week. But in August of that year the national government announced that the allowance would be withheld from immigrants until they had completed two years' residence in the country. In other words, it removed this support for immigrants only in the first two critical years of adjustment to the country, when the government itself is apparently keen for migrants to learn English. Beyond the language question, the significance of this move is that the government was apparently willing to discriminate between migrants and other residents in publicly funded financing of students.

There appears to be no state-supplied support for immigrants on arrival. As some interviewees noted, historically since World War II, other rich English-speaking countries like Australia, Canada, the United States, and the United Kingdom have variously provided some kinds of transitional support structures such as funded language training, translation and interpreting services in federal or provincial institutions, assistance in cultural adaptation, and sometimes accommodation services. According to the informants interviewed, any such support seems totally lacking in New Zealand except possibly for refugees.

\section{The Lives of Learners}

Permanent resident immigrants outnumbered international (visa) students, but both groups expressed high motivation for learning English, a point that is backed up by the teachers and administrators. Learners either pointed to their continuing existence as residents in New Zealand, or less often floated the possibilities of living and working in other English-speaking countries like the US. Meanwhile, some left open the option of returning to their home country, for example, in Southeast Asia, where it would be important to use English for international purposes.

For those planning to stay in New Zealand, the striking feature was that many needed to make a career shift away from the education, training, and occupation that preceded their move to New Zealand. Many such immigrants already had degrees and/or professional qualifications, but faced stringent obstacles to practicing in these fields in the new country. At least three factors contributed to the shift. One was English: the need to be able to function at a suitable professional level in an area like medicine or pharmacy. A second factor was the need to gain the appropriate professional qualifications in New Zealand to be acceptable to the occupation concerned, and in general to get entry to the professional field. The third factor was the need to get a job. Each of these three roadblocks was daunting enough in itself, 
though often all three were lumped together, decisively turning the migrant in a different direction, for example, into business or computer technology.

The outcome was great uncertainty. Migrants could not be at all sure what lay ahead if their previous occupation was closed to them. There was no guarantee that a new field would be any more feasible, especially as some of the previous problems were still lurking: English language, for instance, or difficulty getting into an occupational field.

Compounding the problem was access to English outside the educational institution, even though these immigrants lived in an English-language environment. For most of the adult migrants interviewed, by far the greatest contact with fluent English speakers was in the ESOL course rather than in the society at large. In the polytechnics learners noted that their main contact with English was the teacher. Beyond the ESOL class, learners had minimal contact with other students in the institution, mostly staying in their own ethnic group or with other ESOL learners. For students at secondary school, the situation was more positive; they reported mixing with both ESOL students and fluent speakers of English through the variety of structures and opportunities provided by the school system in general.

Asked about their contact with "local Kiwis" or other users of English, some learners pointed to semistructured situations like shopping and church, while making it plain that exchanges in English in these settings were fairly limited. The reality for many was that outside education circles, they had only fleeting use of English in New Zealand. When they went home they returned, naturally enough, to their mother tongue and their own home-culture community. They clearly had real difficulty in meeting Anglophone New Zealanders (Henderson, Watts, \& Trlin, 2000).

Both older and younger migrants referred to the value of mass media. Many learners mentioned that they used radio, often in the car, and many drew an interesting distinction. It is often claimed that television is a prime means and motivator for language learners, but many of these learners said that the visual medium itself was a distraction: they tended to concentrate on the images on screen at the expense of the language. The advantage of radio to many migrants was that "they had to concentrate on the language," and as a result, radio was more beneficial.

\section{The Views of Teachers and Administrators}

The teachers and administrators in the survey described the migrants' situation in terms that paralleled the migrants' own accounts. Teachers reported that overwhelmingly learners were strongly motivated to learn English. Teachers note that migrants come with a wide range of abilities in English, that they mostly aspire to become proficient in English in order to survive in society and get employment. With these concerns in mind, and aware of the potential advantages of the rich English-language environment available, 
teachers described how they tried to channel their learners to interactive encounters with English-speakers outside of class.

Teachers recognize that migrants often could not achieve their dreams. One teacher-administrator described the "migrant curve": the migrant arrives with hopeful expectations of building on his or her professional qualifications and experience, only to face the unpleasant reality that such dreams are unlikely to come true because of the demands outlined above, including language. For some time, they live in denial or increasing despair and disillusionment. Having descended into a period of uncertainty and hopelessness, the single factor that helps lift the migrant is to see the need to make a career shift and then to set about getting the vocational qualifications to do so. At this point the migrant's life starts to improve, and there is some hope.

In commenting on the ESOL profession teachers referred to both internal and external pressures and developments. In the language teaching profession many noted a general skill upgrading of language teachers over the last decade including moves to gain higher academic qualifications for ESOL (many had been engaged in part-time study), greater professionalism, and stronger emphasis on standards and testing in their teaching. Meanwhile, various teachers commented on the changing social structure, including the restructuring of society starting in the 1980 s and still continuing. They described the political decision to open immigration in the early $1990 \mathrm{~s}$ as a means of enhancing New Zealand's "human capital." They also recounted the turbulence created by an influential cabinet minister Winston Peters, who moved to restrict immigration around 1993. As they tell it, a backlash against visible minorities flowing into the country resulted in a tightening of English-language testing in 1995, when the country adopted the IELTS for screening applicants.

This development was then followed by a slight loosening of test standards for business class migrants a year or so later when the New Zealand government apparently became alarmed that its immigration numbers were dropping, thereby reducing the financial gains the immigration policy was supposed to promote. Teachers and administrators were conscious of the uncertainty such moves created both for instructors and learners. Some pointed out the difficulties of planning properly when numbers of immigrants fluctuated sharply over the years. In the context of the evident competition now officially fostered among teaching institutions, various interviewees commented on the unease created by just-in-time government funding procedures for certain language programs, often those focused on employment. Certain government agencies in particular would apparently delay confirmation of funding for programs until the last minute, with the result that the education institutions had to scramble to find teachers and 
resources and often found that their contract teachers of necessity had taken other teaching positions elsewhere.

\section{Costly Benefits}

It is disturbing to realize that many immigrants to New Zealand face marked uncertainty, often involving more than a career shift. Despite all their efforts to master English, change occupations, gain qualifications, and earn a living, they may be headed for subsistence or worse. There are numerous unsettling questions about immigration that at some point afflict ESOL programs. One of the most troubling problems can be coping with the bewildering shifts in government policy as legislators lurched from open doors, to warning signals that migrants were not welcome, to restrictive and changing English language requirements. There are two obvious dangers from the erratic course of government policy. First, internationally New Zealand may fail the test of a consistent and humane policy of immigration. Second, internally the climate created for migrants must surely be insecure, unstable, and unwelcoming, reminiscent of the early postwar days of "white immigration" policies in Australasia, with all the racist and ethnocentric baggage that went with them.

There is also uncertainty and pressure on the institutions providing ESOL programs, especially the polytechnics. If learners need rich, meaningful, interactive access to the target language to succeed, then the burden is on ESOL teachers and programs to provide the bulk of the English-language environment because the learners often do not have much contact with English outside of class, a situation that limits one of the single best avenues for extensive and continuing language learning.

Many of the migrant interviewees were poorly prepared for the career changes they needed to make. None suggested they had been warned that their previous experience or qualifications might not open equivalent or similar occupations in New Zealand. Separately, the $\$ 20,000$ bond tied to performance on the IELTS looked like a simple cash-grab from a vulnerable category of resident. And the national government's decision to remove the study allowance for immigrants in the first two years of residence was plain discrimination. Presumably, the government both had a constituency that favored such moves and was relying on tacit support from the New Zealand public. If opinions in the media were anything to go by, they may have been right; there was little reported objection or commentary at the time, even though the first two years are obviously the most crucial time for migrants to become proficient in English. In any case, the change in policy violated the stated rights of all immigrants that they enter the country as residents, with the rights and privileges of other New Zealand residents, except for citizenship itself. Some of the New Zealand citizens interviewed compared New Zealand unflatteringly with other countries, pointing out that Australia has 
for years provided some 800 hours of paid language instruction for immigrants, although this has recently been cut back.

It is troubling to recognize the lack of transitional support for migrants (Skinner, Trlin, Henderson, \& North, 2000). In contrast to other rich Western countries, New Zealand has adopted a laisser-faire approach that effectively tells immigrants they can sink or swim, but the state will not intervene to buoy them up in the difficult early period of adjustment to the new society. Above all New Zealand needs a resettlement program for migrants to provide language instruction, cultural adjustment, translation and interpreting, help with initial accommodation, and employment. As Ho, Cheung, Bedford, Leung (2000) put it, there is a need for "one-stop shops" "to help meet the everyday needs of recent migrants," and services to provide English-language training, employment assistance, and access to information and support networks (pp. 35-36). Such a move would be much more than just a humane gesture to ease entry to the country. It would be a significant social investment in the lives of the migrants and in the future of New Zealand society.

Two dominant conclusions remain. First, the headlong rush of New Zealand's political and business leaders to undo the public sector has jettisoned the institutional structures that would enhance the potential offered through immigration. The lack of settlement programs short-changes New Zealand's own policies of opening to larger-scale immigration. Arguably, neither the migrant nor the country stands to benefit richly or swiftly from the presence of new populations in the present situation.

Second, the situation of migrants and of ESOL has called for some concerted response from the professionals in the relevant fields including: (a) public lobbying on behalf of migrants; (b) mobilizing teachers, citizens, or community groups to become involved in public debate and organizing; (c) making proposals for public policies relating to immigration and ESOL; and (d) cooperative planning within or across institutions and organizations. All these initiatives have taken place, though with some difficulty, due to an environment that until the election of 1999 did not encourage political activism or collective endeavor. In any case, people's lives are already stretched. Any instructors who conscientiously teach 20 or more hours a week in a polytechnic, for instance, along with preparation, marking, tutoring, and advising, have little time left for any action beyond their coursework. There is, however, a mood of cautious optimism since the election of the Labour-Alliance government in 1999 that ushered into power parties that have overtly favored more progressive social policies than their predecessors, including more humane immigration (Dalziel, 1999).

\section{New Zealand and Canada}

The developments in New Zealand have some relevance for Canada. The processes of globalization and structural adjustment are indeed global, and 
Canada is now experiencing internally the kinds of restructuring that New Zealand has gone through since the mid-1980s: a diminishing government role in society; an insistent push to develop a market economy; extensive cuts in federal government transfer payments to the provinces for health and education; and systematic restructuring of society, local government, and education in Alberta and Ontario with the advent of Tory governments under Ralph Klein and Mike Harris respectively (Barlow \& Campbell, 1995; Clarke, 1997; Dobbin, 1998; McQuaig, 1995; Ralph, Regimbald, \& St-Amandet, 1997). In Ontario government cutbacks effectively demolished the immigrant support and English language teaching function of the Ministry of Citizenship, one of the pioneers in the field. This process has done away with Welcome House, a point of first contact for many immigrants that used to provide ESL, interpreting and numerous immigrant services.

Meanwhile, it is instructive to consider Simmons' $(1997,1998)$ analysis of Canada's "pragmatic" and "entrepreneurial" immigration policies as Canada tries increasingly to "attract larger portions of highly skilled professional workers, entrepreneurs and investors" (1997, p. 44) in an attempt to "make the Canadian economy more productive, competitive, and profitable" (p. 44). In his analysis Canada is positioning itself to transform the country into "a sophisticated niche-player in the new global trade system," through the "human capital" of skilled "designer immigrants" - "self-financed professionals and skilled business immigrants who come without any need of further training for productive roles in the economy" (p. 44). Simmons recognizes two kinds of immigrants, "the elite business and investor class," on the one hand, and "impoverished" refugees, on the other (p. 58). In other words, he sees globalization increasing "the divide between 'winners' and 'losers' in the international system" (p. 58).

Many of these aspects are reminiscent of New Zealand's immigration policies summed up in Dale and Robertson's (1997) analysis of New Zealand as "resiting" geopolitically in moving to attract a relatively wealthy class of educated immigrant. In the light of New Zealand losing its former British markets, the country has now "sought to redefine its identity in terms of a new pole of political and economic growth and power: the 'Asia-Pacific'" (p. 213). Dale and Robertson quote Baba, arguing that New Zealand's relationship with the Pacific has moved from "'benevolence' to one of 'profiteering' and a more overt neo-colonialism" (p. 214). "Resiting the nation," they conclude, "can be seen as essentially a market-oriented strategy to enable the continuing development of the New Zealand-Asia-Pacific trade relationship" (p. 215). At the same time the country has moved to "reshape" itself into a "competitive state," emphasizing principles of competitiveness, deregulation, and privatization.

In this discussion from different sides of the Pacific, one of the conclusions might well apply to either country: "Immigration strategies may 
therefore be understood as one component of a broader set of economic, skill-training, and social policies that together seek to transform the nation" (Simmons, 1997, p. 44).

The issue of immigration is a contentious and often volatile matter. Public opinion on the topic is dynamic and divisive, and immigration policy can change decisively over time. A case in point is a press statement by Canada's Citizenship and Immigration Minister Elinor Caplan in January 2000 (Thompson, 2000), envisaging a sharp increase from the targets of 200,000225,000 in 1998-1999 to 300,000 per year. Among other points, Caplan was considering abolishing the point system and enhancing programs to speed entry of "skilled workers needed to meet labour shortages." According to Thompson, Caplan explains the change of policy as an "important part of dealing with an aging population and sustaining Canada's pension and health-care systems." And somewhat in line with Simmons' comments above, she comments, "we're looking at selection systems that will be flexible enough to respond to our needs in the future."

\section{Future Directions}

There are some clear directions for further investigation of ESOL and related fields. One is to explore policy issues at the level of governments and institutions as they relate to ESOL, immigration, and education, inquiring into the conditions set up for migration, language learning, teaching, and institutional planning. A second, recognizing continuing studies of immigration in New Zealand, is to map and analyze the situation of migrants' lives, their opportunities for English-language learning, interaction with the English language environment, and the relationship of language-learning to survival, residence, income and career, and enjoyment of life in New Zealand or elsewhere. A third is to explore the role of relevant education institutions, teachers' associations, and community organizations in enhancing the lives of migrants both in relation to education and to public policy.

\section{Acknowledgments}

The research reported on here was funded by three grants from York (York University Incentive Grants, York Social Sciences and Humanities Research Council Small Grants, and Faculty of Education Research and Development Grants). Others whose support is gratefully acknowledged in making the research possible include Prof. Rod Ellis and the Institute of Language Teaching and Learning, University of Auckland, Margaret James, Alan McDonald, Nick Shackleford, and Allan Vester.

\section{The Author}

David Cooke is a New Zealand and Canadian citizen who has been engaged in English-language education in New Zealand, the United Kingdom, Canada, Cuba, Mozambique, Nicaragua, and the People's Republic of China. He is an associate professor of education and English at York University, Toronto. 


\section{References}

Barlow, M., \& Campbell, B. (1995). Straight through the heart: How the Liberals abandoned the Just Society and what Canadians can do about it. Toronto, ON: Harper Collins.

Bedford, R., \& Bedford, C. (2000, April 12-13). International migration in the first decade of the 21st century: What have we learnt from the 1990s? Paper presented to New Directions: New Settlers-Migration and New Zealand Society into the 21st Century, Seminar, Victoria University of Wellington.

Clarke, T. (1997). Silent coup: Confronting the big business takeover of Canada. Ottawa: CCPA; Toronto, ON: Lorimer.

Clarke, T., \& Barlow, M. (1997). MAI the multilateral agreement on investment and the threat to Canadian sovereignty. Toronto, $\mathrm{ON}$ : Stoddart.

Dale R., \& Robertson, S. (1997). "Resiting" the nation, "reshaping" the state: Globalization effects on education policy. In M. Olssen \& K. Matthews (Eds.), Education policy in New Zealand: The 1990s and beyond (pp. 209-227). Palmerston North, NZ: Dunmore Press.

Dalziel, L. (1999, October 7). Panel presentation, Forum on "Immigration: opportunity or cost." Auckland, NZ: UNITEC Institute of Technology.

Dobbin, M. (1998). The myth of the good corporate citizen: Democracy under the rule of big business. Toronto, ON \& New York: Stoddart.

Easton, B. (1997). The commercialisation of New Zealand. Auckland, NZ: Auckland University Press.

Else, A. (1996). False economy: New Zealanders face the conflict between paid and unpaid work. Birkenhead, North Shore City: Tandem Press.

Forsyte Research. (1998, May 7). Experience of the English language bond. Wellington: New Zealand Immigration Service.

Henderson, A., Watts, N., \& Trlin, A. (2000, April 12-13). Social participation, settlement factors and integration: The experiences of skilled Chinese immigrants. Paper presented to New Directions: New Settlers-Migration and New Zealand Society into the 21st Century, Seminar, Victoria University of Wellington.

Ho, E., Cheung, E., Bedford, C., \& Leung, P. (2000, March). Settlement assistance needs of recent migrants. Wellington: New Zealand Immigration Service.

Kelsey, J. (1995). The New Zealand experiment: A world model for structural adjustment? Auckland, NZ: Auckland University Press with Bridget Williams Books.

Kelsey, J. (1999). Reclaiming the future: New Zealand und the global economy. Wellington: Bridget Williams Books.

Kennedy, S., \& Dewar, S. (1997). Non-English-speaking background students: A study of programmes and support in New Zealand schools. Wellington: Ministry of Education.

Mander, J., \& Goldsmith, E. (1996). The case against the global economy: And for a turn toward the local. San Francisco, CA: Sierra.

McQuaig, L. (1995). Shooting the hippo: Death by deficit and other Canadian myths. Toronto, ON: Penguin.

Ralph, D., Regimbald, A., \& St-Amand, N. (1997). (Eds.). Open for business, closed to people: Mike Harris's Ontario. Halifax, NS: Fernwood.

Richardson, B. (1996, March). Surviving the "miracle." Canadian Forum (Toronto), pp. 12-14.

Roberts, P. (1997). A critique of the NZQA policy reforms. In M. Olssen \& K. Matthews (Eds.), Education policy in New Zealand: The 1990s and beyond (pp. 162-189). Palmerston North: Dunmore Press.

Roberts, P. (1998). The politics of curriculum reform in New Zealand. Curriculum Studies, 6, 1, 29-46.

Skinner, M., Trlin, A., North, N. (2000, April 12-13). Old country connections: The importance of relatives and friends in international migration. Paper presented to New Directions: New 
Settlers-Migration and New Zealand Society into the 21st Century, Seminar, Victoria University of Wellington.

Simmons, A. (1997, November). Canadian immigration and nation building: Social and political implications of recent trends. In Canada: Horizons 2000. Actes du collogue tenu au College universitaire de Saint-Boniface (pp. 43-70). Presses universitaires de Saint-Boniface.

Simmons, A. (1998, October 3). Immigration research: The state of the art. Paper presented to CERIS (Centre of Excellence for Research on Immigration and Settlement), Building Research Links: Working seminar on immigration and settlement in the Greater Toronto Area. Toronto, ON: York University.

Thompson, A. (2000, January 14). Immigrant policies to be more "flexible." Toronto Star, p. 1.

\section{Appendix: Interviews: Sample questions for language learners}

\subsection{Aims}

a What are your aims in taking ESL?

b What will you use English for?

1.2 Needs

a What do you need English for now?

b What will you need English for in the future?

1.3 Ultimate Goals

a Are you likely to stay in NZ to live?

b Are you likely to live in some other country?

(1) English-speaking

(2) Non-English-speaking

(3) Both (1) \& (2)

c Are you likely to have a mixture of (a) \& (b) above? (i.e., sometimes living in NZ and sometimes in another country).

1.4 Connection: To what extent do your current courses fit your aims, needs and goals stated in answer to the first three questions?

1.5 Preferred Ways of Learning:

a What are your preferred ways of learning English

e.g., analytical study (grammar, structure ...); experience of the language in natural settings; practice for a course, programme, book, multimedia; practice of listening, speaking, reading, writing; use of language lab

b How? In what way?

c How do you most like to learn English?

d How do you least like to learn English?

1.6 Learning Procedures: To what extent do you make use of books, texts, TV, audio, meeting people, overhearing conversations?
[3 - a great deal
2 - some
1 -a little 0 - none]

1.7 Motivation:

a How would you describe your drive / motivation to learn English?

b To what extent do you want to learn English?
[3 - a great deal
2 - some
1 - a little
0- none]

1.8 Progress in English

Different factors can help or hinder your progress in English: e.g., English itself; the ESL courses you take; facing NZ culture(s); income; housing / accommodation; acceptance or rejection by different people; time available to study. Considering language and or other factors,
a What encourages your progress in English?
b What inhibits your progress in English? 